\title{
LETTER
}

\section{Newly discovered garnet-barroisite schists from the Heilongjiang Complex in the Jiamusi Massif, northeastern China}

\author{
Weimin LI $^{*}$, Akira TAKASU*, Yongjiang LIU ${ }^{* *}$ and Xinzhuan GuO ${ }^{* * *}$ \\ "Department of Geoscience, Shimane University, Matsue 690-8504, Japan \\ ${ }^{* *}$ College of Earth Sciences, Jilin University, Changchun 130061, Jilin, P.R. China \\ ${ }^{* * *}$ Institute for Study of the Earth's Interior, Okayama University, \\ Misasa, Tottori 682-0193, Japan
}

\begin{abstract}
Newly found garnet-barroisite schists from the Heilongjiang Complex in the Yilan area, northeastern China, are petrographically described. They are composed mainly of albite, amphibole, phengite, epidote, garnet, quartz, titanite and magnetite, with minor amounts of stilpnomelane, apatite, hematite, rutile, and ilmenite. The metamorphism of the garnet-barroisite schists are divided into three stages: pre-peak stage of the epidote-blueschist facies; peak stage of the epidote-amphibolite facies $\left(T=500-540^{\circ} \mathrm{C}\right.$ and $\left.P=10-12 \mathrm{kbar}\right)$; and retrograde stage of the greenschist facies. These results reveal a clockwise high $-P / T$ path for the garnet-barroisite schists in the Heilongjiang Complex.
\end{abstract}

Keywords: Blueschist, Garnet-epidote-amphibolite, Heilongjiang Complex, Jiamusi Massif, Northeastern China

\section{INTRODUCTION}

The Jiamusi Massif is located in northeastern China along the eastern border of the Central Asia Orogenic Belt, which lies between the Siberian and Sino-Korean cratons (Fig. 1; Sengör et al., 1993). The Jiamusi Massif is composed mainly of granulitic basement (Mashan Complex) of $\sim 500 \mathrm{Ma}$ in metamorphic age (e.g., Wilde et al., 2003), Early Paleozoic granitic intrusions, and metamorphosed Jurassic accretionary complex (Heilongjiang Complex) (Fig. 1; Wu et al., 2007). The Heilongjiang Complex consists predominantly of alternation of blueschists and pelitic schists with thin intercalation of siliceous schists and marbles. Ultramafic bodies having various sizes occur in high-pressure type schists. This rock association is considered as accretionary material in a subduction zone between the Jiamusi and the Songnen massifs (Cao et al., 1992; Wu et al., 2007).

Previous research on high- $P$ type metamorphic rocks of the Heilongjiang Complex suggested a clockwise metamorphic $P-T$ evolution, i.e., peak blueschist facies metamorphic stage and retrogressed greenschist facies metamorphism (e.g., Bai et al., 1988; Ye et al., 1994). The

doi:10.2465/jmps.091015d

W.Li, weimin_L2003@yahoo.com Corresponding author peak metamorphic conditions of the blueschists exposed in the Mudanjiang and Yilan areas were suggested as $T=$ $350-450{ }^{\circ} \mathrm{C}$ on the basis of the temperature range of the epidote-blueschist facies conditions and $P=6-7$ kbar using the $b_{0}$ values of phengites (Bai et al., 1988); however, the estimation of pressure by the $b_{0}$ value of phengite is unreliable (Massonne and Schreyer, 1987). Recently, Li et al. (2009) reported blueschists exposed in the Yilan area that consist of glaucophane, phengite, epidote, albite, chlorite, titanite, and quartz. Phengites have high Si contents ( $\mathrm{Si}=6.70-6.90$ p.f.u.), suggesting high- $P$ metamorphic conditions. Blueschist facies metamorphic rocks in the Heilongjiang Complex yielded phengite ${ }^{40} \mathrm{Ar} /{ }^{39} \mathrm{Ar}$ ages of 161-175 Ma and 145-146 Ma (e.g., Wu et al., 2007; Li et al., 2009), probably suggesting multiple events of metamorphism and exhumation for high- $P$ type metamorphic rocks.

In this paper, we provide a petrographic description of newly found garnet-barroisite schists from the Heilongjiang Complex, Yilan area (Fig. 1), and discuss their $P-T$ evolution. Our results presented here in conjunction with previously published data reveal that the peak metamorphic conditions obtained for the Heilongjiang Complex vary in different areas, from the epidote blueschist facies to the epidote amphibolite facies. The age and char- 


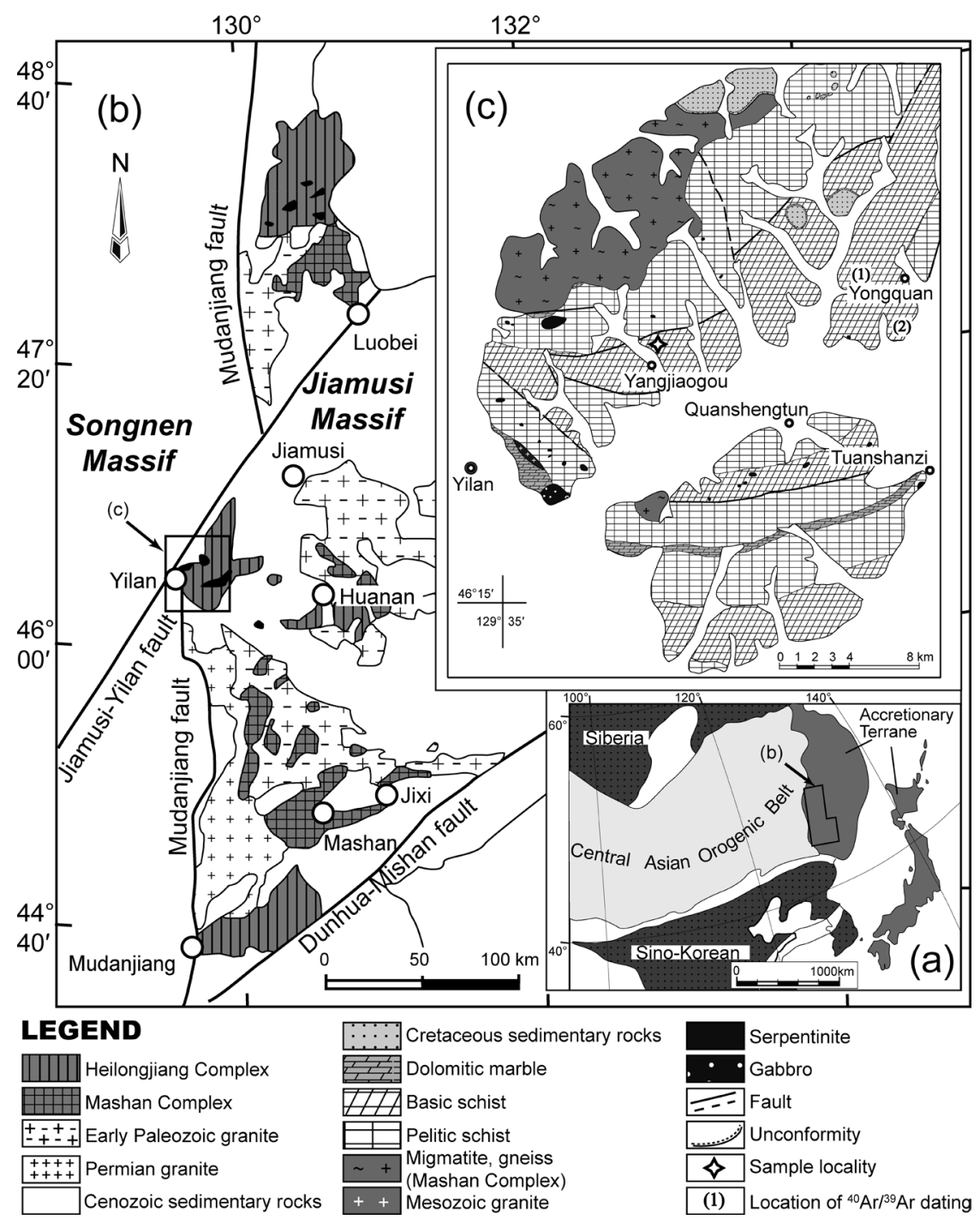

Figure 1. Simplified geological maps of the study area. (a) Geotectonic map of the eastern Asia (after Sengör et al., 1993). (b) Geological sketch map of the Jiamusi Massif (Wu et al., 2007). (c) Geological map of the Yilan area (after Huang et al., 2008) showing the sample locality and the locations of the samples dated by the ${ }^{40} \mathrm{Ar}{ }^{39} \mathrm{Ar}$ method (Li et al., 2009), whereas (1) represents the locality of the pelitic schist with an age of $171 \mathrm{Ma}$ and (2) represents that of blueschist with an age of 145-146 Ma.

acteristics of the metamorphism are similar to those of the Suo metamorphic belt, southwest Japan (e.g., Nishimura, 1998), and the results presented in this paper contribute toward the consideration of the Jurassic tectonics along the eastern margin of the Eurasian continent.

\section{REGIONAL GEOLOGY OF THE YILAN AREA}

The Yilan area is located at the western margin of the Jiamusi Massif, and it is bounded by the Mudanjiang Fault to the west and the Jiamusi-Yilan Fault to the northwest (Fig 1). The Heilongjiang Complex exposed in the Yilan area is characterized by the occurrence of alternation of blueschists and pelitic schists with intercalation of thin layers of siliceous schists and marbles. Several serpentinized peridotite bodies having various sizes occur locally and these are in tectonic contact with other metamorphic rocks (Wu et al., 2007). The exact distribution of the various rock types has not been fully investigated because of limited exposures due to deep weathering and heavily vegetated conditions.

The garnet-barroisite schists were collected approximately $1 \mathrm{~km}$ to the north of Yangjiaogou village (Fig. 1c), where they are overlied by pelitic schists. Serpentinite exposures are scattered to the north of the garnet-barroisite schists; however, the geological relationship between the schists and the serpentinites has not yet been clarified because of poor exposures in this area.

\section{PETROGRAPHY OF GARNET-BARROISITE SCHISTS}

The garnet-barroisite schists consist mainly of albite, amphiboles (glaucophane, barroisite, and actinolite with rare katophorite and winchite), phengite, epidote, garnet, quartz, titanite, and magnetite, with minor amounts of stilpnomelane, apatite, hematite, rutile, and ilmenite. A schistosity is well defined by the preferred orientation of 


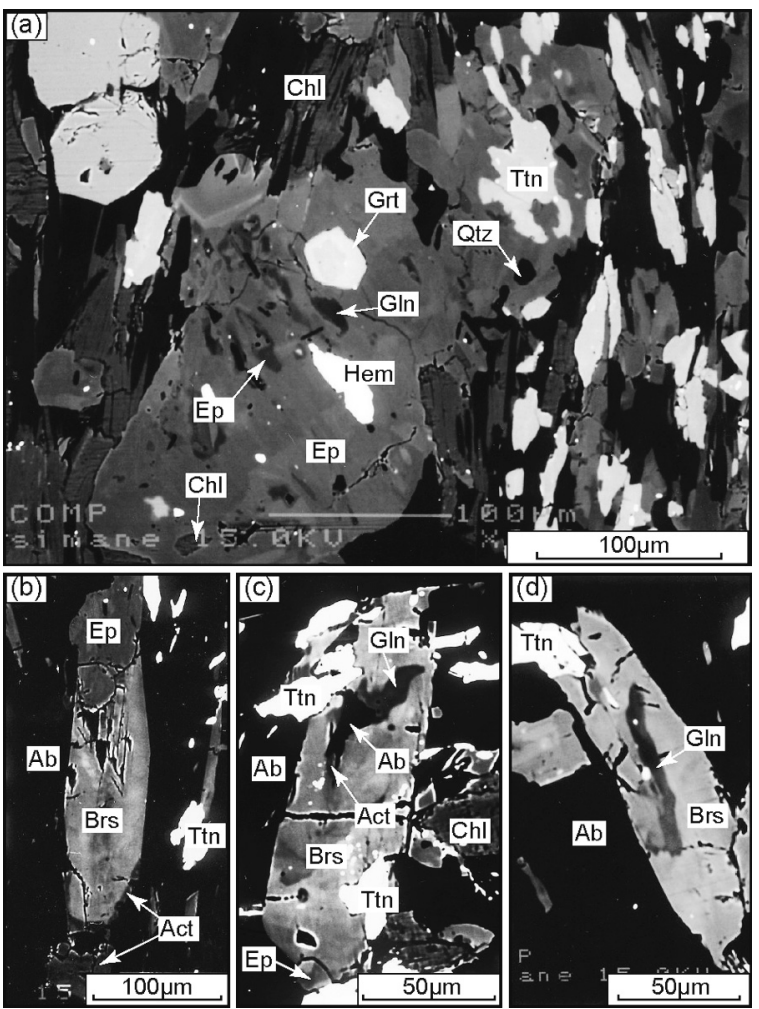

Figure 2. Backscattered electron images of garnet-barroisite schists. (a) Porphyroblastic epidote contains inclusions of glaucophane, garnet, epidote, chlorite, and hematite. (b) Barroisite included in porphyroblastic albite is rimmed by actionlite. (c) Barroisite in porphyroblastic albite includes glaucophane, actinolite, and albite. (d) Barroisite in porphyroblstic albite includes glaucophane.

chlorite, phengite, and amphibole (barroisite).

Albite occurs as anhedral granular porphyroblasts that are up to $3 \mathrm{~mm}$ across. It contains inclusions of amphiboles (actinolite, barroisite, winchite, and katophorite), garnet, epidote, phengite, and chlorite, with minor amounts of stilpnomelane, titanite, and hematite. Some large grains of phengites ( $\mathrm{Si}=6.60-6.65$ p.f.u.) in porphyroblastic albite occasionally include relict grains of former phengites ( $\mathrm{Si}=6.27-6.50$ p.f.u.). The internal schistosity of the inclusions in the albite porphyroblasts is concordant with and continues to the external schistosity in the matrix, indicating post-kinematic growth of albite porphyroblasts. Epidote porphyroblasts that are up to $1 \mathrm{~mm}$ across contain inclusions of glaucophane, phengite, garnet, chlorite, epidote, quartz, titanite, and hematite. Although the alignment of inclusions in epidote porphyroblasts is oblique to the external foliation, it continues to the external schistosity in the matrix. These suggest synkinematic growth of epidote porphyroblasts with rotation (Fig. 2a).

Amphibole (barroisite) occurs in the matrix in the form of subhedral prismatic grains that are up to $0.5 \mathrm{~mm}$ long, and it occasionally contains relict grains of actino- lite of anhedral form that are up to $20 \mu \mathrm{m}$ across. On the other hand, barroisite is generally rimmed by actinolite, and it is occasionally replaced by chlorite along the rim. Amphibole (barroisite) included in the albite porphyroblasts occurs in the form of subhedral grains that are up to $0.2 \mathrm{~mm}$ long and it occasionally exhibits a zoning pattern similar to that of the barroisite in the matrix (Fig. 2b). In addition, the barroisite contains relict grains $(<40 \mu \mathrm{m})$ of glaucophane and actinolite together with albite (Figs. 2c and $2 \mathrm{~d}$ ).

Garnet mainly occurs as inclusions in porphyroblastic albites and rarely in porphyroblastic epidotes. It occurs in the form of subhedral granular grains that are up to 0.1 $\mathrm{mm}$ across with minor inclusions of quartz, epidote, and ilmenite. It is replaced by chlorite along the rim and cracks.

Titanite occurring in the porphyroblastic albites generally contains fine-grained mineral inclusions of rutile, ilmenite, quartz, and chlorite. Stilpnomelane shows the randomly oriented aggregates in the matrix as well as in the albite porphyroblasts. Magnetite occurs in the form of euhedral grains that are up to $1.5 \mathrm{~mm}$ across, and it crosscuts the schistosity. Minor amounts of hematites that are up to $0.3 \mathrm{~mm}$ across are present in both the matrix and the porphyroblastic albites.

\section{MINERAL CHEMISTRY}

The chemical compositions of minerals were analyzed using a JEOL JXA-8800M electron microprobe analyzer at the department of Geoscience, Shimane University. The analytical conditions were as follows: accelerating voltage, $15 \mathrm{kV}$; probe current, $2 \times 10^{-8} \mathrm{~A}$; and probe diameter, $5 \mu \mathrm{m}$. The representative chemical compositions of the minerals are available in Table 1 (available online from http://www.jstage.jst.go.jp/browse/jmps). The abbreviations of minerals and end-members used in Table 1 and Figures 2, 3 and 4 are referred from Kretz (1983) except for the following ones: Phn, phengite; Brs, barroisite; and Wnc, winchite. For the $\mathrm{Fe}^{3+}$ estimation for amphibole, a normalization factor of $13 \mathrm{eCNK}(\mathrm{O}=23)$ was used, and the classification of amphibole was referred from Leake et al. (1997). $\mathrm{Fe}^{3+}$ in the garnet was estimated by $\mathrm{Fe}^{3+}=$ 8-2Si-2Ti-Al $(\mathrm{O}=12)$.

\section{Amphibole}

Amphiboles occurring in the matrix are classified as barroisite $\left(\mathrm{Si}=6.86-7.39\right.$ p.f.u., $\mathrm{Na}_{\mathrm{B}}=0.69-0.94$ p.f.u., and $\left.\mathrm{X}_{\mathrm{Mg}}\left[=\mathrm{Mg} /\left(\mathrm{Mg}+\mathrm{Fe}^{2+}\right)\right]=0.40-0.54\right)$, and they are rimmed by actinolite $\left(\mathrm{Si}=7.65-7.88\right.$ p.f.u., $\mathrm{Na}_{\mathrm{B}}=0.22-$ 0.37 p.f.u., and $\mathrm{X}_{\mathrm{Mg}}=0.57-0.65$ ). Amphiboles present as 
inclusions in the porphyroblastic albites exhibit compositional zoning similar to that of the barroisites in the matrix. The core of barroisite ( $\mathrm{Si}=6.69-7.46$ p.f.u., $\mathrm{Na}_{\mathrm{B}}=$ $0.52-1.04$ p.f.u., and $\left.\mathrm{X}_{\mathrm{Mg}}=0.33-0.60\right)$ is rimmed by actinolite ( $\mathrm{Si}=7.54-7.94$ p.f.u., $\mathrm{Na}_{\mathrm{B}}=0.16-0.49$ p.f.u., and $\left.\mathrm{X}_{\mathrm{Mg}}=0.51-0.63\right)$. The other amphiboles included in the albites are chemically classified as winchite and katophorite ( $\mathrm{Si}=6.80-7.64$ p.f.u., $\mathrm{Na}_{\mathrm{B}}=0.58-0.95$ p.f.u., and $\mathrm{X}_{\mathrm{Mg}}$ $=0.33-0.57$ ). Sodic amphiboles present as inclusions in the porphyroblastic epidotes and in the barroisites occurring in the albites have chemical compositions similar to those of glaucophane ( $\mathrm{Si}=7.71-8.00$ p.f.u., $\mathrm{Na}_{\mathrm{B}}=1.57-$ 1.90 p.f.u., and $\mathrm{X}_{\mathrm{Mg}}=0.46-0.52$ ).

\section{Garnet}

Garnets included in the porphyroblastic albites and epidotes have similar chemical compositions ( $\mathrm{Alm}_{41-69}, \mathrm{Sps}_{8-39}$, $\left.\mathrm{Grs}_{15-34}, \mathrm{Py}_{1-5}\right)$. They exhibit a compositional zoning with increasing $\mathrm{Fe}^{2+}$ (1.36-1.85 p.f.u.), $\mathrm{Mg}(0.07-0.11$ p.f.u.), and $\mathrm{Ca}(0.63-0.72$ p.f.u.) and antipathetically decreasing in $\mathrm{Mn}(0.93-0.31$ p.f.u.) from the core to the rim.

\section{Phengite}

The Si content of phengites in the matrix is $6.52-6.80$ p.f.u. with low $X_{\mathrm{Na}}[=\mathrm{Na} /(\mathrm{Na}+\mathrm{K})]$ of $0.01-0.07$. Further, the $\mathrm{Si}$ content of phengites included in the porphyroblastic albites and epidotes is $6.52-6.78$ p.f.u. with $\mathrm{X}_{\mathrm{Na}}=$ $0.01-0.09$. Finally, the Si content of phengites included in large phengite grains within the albite porphyroblasts is $6.27-6.50$ p.f.u. with $\mathrm{X}_{\mathrm{Na}}=0.05-0.08$.

\section{Epidote and Titanite}

$\mathrm{X}_{\mathrm{Ps}}\left[=\mathrm{Fe}^{3+} /\left(\mathrm{Al}+\mathrm{Fe}^{3+}\right)\right]$ in porphyroblastic epidotes and epidote inclusions in the albite porphyroblasts are almost homogeneous within each grain; however, the variation of $\mathrm{X}_{\mathrm{Ps}_{\mathrm{S}}}$ among the different grains ranges from 0.17 to 0.33 . The fine-grained epidotes included in the epidote porphyroblasts (Fig. 2a) have relatively low $\mathrm{X}_{\mathrm{Ps}}$ of $0.10-0.14$. Al of titanite is $0.02-0.05$ p.f.u., and $\mathrm{Ti}$ is $0.94-0.99$ p.f.u. $(\mathrm{O}$ $=5)$.

\section{METAMORPHIC EVOLUTION OF GARNET-BARROISITE SCHISTS}

\section{Mineral paragenesis}

Based on the petrography and chemical composition of the constituent minerals, the metamorphism of the garnetbarroisite schists is divided into three metamorphic stages:

\begin{tabular}{|c|c|c|c|}
\hline $\begin{array}{l}\text { Mineral } \\
\text { assemblage }\end{array}$ & Pre-peak (EBS) & Peak (EA) & Retrograde (GS) \\
\hline \multirow{2}{*}{$\begin{array}{l}\text { Amphibole } \\
\text { Epidote }\end{array}$} & relicts (Gln, Act) & Brs & Act \\
\hline & incl. in Ep porphyr. & $\begin{array}{l}\text { incl. in Ab porphyr. } \\
\& \text { Ep porphyr. }\end{array}$ & \\
\hline \multicolumn{4}{|l|}{ Chlorite } \\
\hline \multirow{2}{*}{$\begin{array}{l}\text { Phengite } \\
\text { Albite }\end{array}$} & $\mathrm{Si}=6.3$ p.f.u. - & $-S i=6.8$ p.f.u. & \\
\hline & relic grains in $\operatorname{Brs}(A n<2)$ & & porphyr. (An $<2$ \\
\hline \multirow{2}{*}{\multicolumn{4}{|c|}{$\begin{array}{l}\text { Stilpnomelane } \\
\text { Garnet }\end{array}$}} \\
\hline & & & \\
\hline \\
\hline & & & \\
\hline $\begin{array}{l}\text { Titanite } \\
\text { Fe-oxide }\end{array}$ & Hem \& IIm & $\mathrm{Hem}$ & Mag \\
\hline
\end{tabular}

Figure 3. Mineral paragenesis of the garnet-barroisite schists from the Heilongjiang Complex in the Yilan area. EBS, epidote-blueschist facies; EA, epidote-amphibolite facies; GS, greenschist facies.

pre-peak, peak, and retrograde stages (Fig. 3).

The pre-peak metamorphic stage is characterized by inclusions of glaucophane, actinolite, and albite in the barroisites (Figs. 2c and 2d), as well as relict phengites ( $\mathrm{Si}$ $=6.27-6.50$ p.f.u.) occurring in the coarse-grained phengite. In addition, phengite $(\mathrm{Si}=6.55-6.78$ p.f.u.), epidote, glaucophane, garnet, titanite, and hematite included in porphyroblastic epidotes probably define this stage close to the peak conditions (Fig. 2a). These mineral assemblages suggest metamorphic conditions in the epidoteblueschist facies.

The peak metamorphic stage is characterized by inclusions in the porphyroblastic albites, such as garnet, epidote, barroisitic amphibole including winchite and katophorite, phengite ( $\mathrm{Si}=6.52-6.68$ p.f.u.), chlorite, and hematite along with schistosity-forming minerals of barroisite, phengite $(\mathrm{Si}=6.52-6.80$ p.f.u.), and porphyroblastic epidote. In addition, the relicts of rutile included in the titanites that are present in the porphyroblastic albites probably formed in this stage. These suggest the epidoteamphibolite facies as the peak metamorphic conditions.

Barroisites in the matrix and in the porphyroblastic albites were rimmed by actinolites, whereas garnets and rutiles were replaced by chlorites and titanites, respectively. These suggest greenschist facies conditions in the retrograde stage. The porphyroblastic albite, randomly oriented stilpnomelane, and coarse-grained magnetite were also formed during the retrograde stage.

\section{Metamorphic conditions}

The presence of actinolite in the pre-peak stage suggests the $P-T$ condition through the actinolite stability field (Otsuki and Banno, 1990). The chemical composition of glaucophane coexisting with epidote and hematite from 


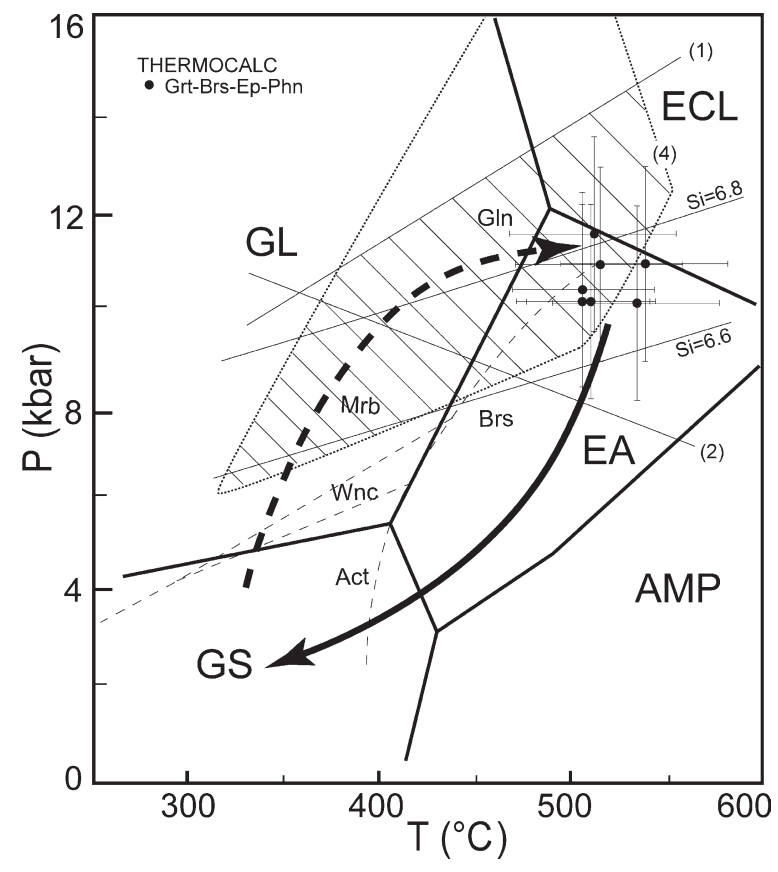

Figure 4. $P-T$ estimation of metamorphic conditions of the garnetbarroisite schists. $P-T$ boundaries of the metamorphic facies are referred from Takasu (1989). Dashed lines indicate the stability fields of Act, Wnc, Mrb, and Brs (Otsuki and Banno, 1990). The dotted line (4) indicates the stability field of glaucophane 4 (Evans, 1990). The isopleths of the Si content in phengite are referred from Massonne and Schreyer (1987). Reaction (1) albite $=$ jadeite + quartz (Holland, 1983). Reaction (2) 2 clinozoisite +5 titanite $=3$ grossular +5 rutile +2 quartz $+\mathrm{H}_{2} \mathrm{O}$ is calculated using the thermodynamic properties reported in Holland and Powell (1998). The diagonally lined area indicates the stability field of the pre-peak metamorphic stage; the broken arrow indicates the possible prograde $P-T$ path; and the solid arrow indicates the retrograde path. ECL, eclogite facies; GL, glaucophane schist facies; EA, epidote-amphibolite facies; AMP, amphibolite facies; GS, greenschist facies.

the garnet-barroisite schists is similar to that of glaucophane 4 defined by Evans (1990). The stability field of the glaucophane and the upper stability limit of albite (Holland, 1983) constrain $P-T$ conditions of $320-550{ }^{\circ} \mathrm{C}$ and 6-15 kbar for the pre-peak stage of the epidote-blueschist facies (Fig. 4). Phengite that does not coexist with $\mathrm{K}$-feldspar and phlogopite provides a minimum pressure (Massonne and Schreyer, 1987). Therefore, phengites $(\mathrm{Si}=6.8$ p.f.u.) included in the porphyroblastic epidotes suggest a minimum pressure of $10 \mathrm{kbar}$ for the prograde stage prior to the peak stage. In addition, the appearance of rutile relicts in the titanites is probably related to the reaction, 2 clinozoisite +5 titanite $=3$ grossular +5 rutile +2 quartz $+\mathrm{H}_{2} \mathrm{O}$, and it defines the lower limit of the pressure of the pre-peak metamorphic conditions close to the peak stage (Fig. 4).

The mineral inclusions of garnet, barroisite, epidote, and phengite in the porphyroblastic albites indicate the peak metamorphic conditions. THERMOCALC (ver. 3.21) with an updated thermodynamic dataset (Holland and Powell, 1998) is used for the $P-T$ estimation of the peak metamorphic stage. The activities of the minerals are obtained using the AX program (Holland and Powell, 1998). The equilibrium mineral assemblages of garnetbarroisite-epidote-phengite yield average $P-T$ conditions of $T=500-540{ }^{\circ} \mathrm{C}$ and $P=10-12 \mathrm{kbar}$ for the peak metamorphic conditions (Fig. 4).

\section{DISCUSSION AND CONCLUSIONS}

The epidote-blueschist facies as the peak metamorphism for the Heilongjiang high- $P / T$ metamorphic rocks has been reported in previous researches (e.g., Bai et al., 1988). The newly discovered garnet-barroisite schists from the Heilongiiang Complex in the Yilan area experienced epidote-blueschist facies conditions before the peak metamorphism of the epidote-amphibolite facies (500$\left.540{ }^{\circ} \mathrm{C}, 10-12 \mathrm{kbar}\right)$. The minimum pressure of $10 \mathrm{kbar}$ for the prograde $P-T$ path suggests the possibility of the presence of a pressure-peak prior to a thermal-peak. The barroisites of the peak metamorphic stage are rimmed by actinolites and the absence of high $-P / T$ type amphiboles such as winchite and glaucophane during the retrograde stage suggests a clockwise $P-T$ evolution of the garnetbarroisite schists (Fig. 4).

The Suo metamorphic belt of southwest Japan is characterized by blueschists of 160-230 Ma in age (Nishimura, 1998). Lenses or blocks of garnet-barroisite schists occur in serpentinite bodies in the Gotsu district in the Suo belt. The mode of occurrence and petrographic characteristics are similar to those of the garnet-barroisite schists described in this paper (Sengan, 1985; Nishimura, 1998). Additionally, the metamorphic ages of the Suo belt are also similar to or slightly younger than those of the Heilongjiang Complex (145-175 Ma; Li et al., 2009). Before the Japan Sea opened at $\sim 15 \mathrm{Ma}$ (Otofuji and Matsuda, 1983), the Heilongjiang high- $P / T$ metamorphic rocks probably continued to the south. The Suo metamorphic belt in southwest Japan is thus a possible southern extension of the Heilongjiang Complex. It is probable that the Heilongjiang Complex is proximal and the Suo belt is distal with respect to the original subduction site, based on the slightly younger ages of the Heilongjiang Complex relative to the Suo belt. The results reported here and further precise petrological and geochronological studies will contribute toward a better understanding of the Mesozoic tectono-metamorphic development of the eastern margin of the Eurasian continent. 


\section{ACKNOWLEDGMENTS}

We are grateful to Drs. M. Enami, J. Gao, Y. Banno, and B.P. Roser for their detailed and constructive reviews. We thank the members of the Metamorphic Seminar and the Geoscience Seminar, Shimane University for the helpful discussion and suggestions. We also thank Drs. X.Z. Zhang, Y.L. Zhao, and G.Q. Han of the College of Earth Sciences, Jilin University, for their help in the field. This study was partly supported by a JSPS Grant-in-Aid for Scientific Research (No. 17340149) to A. T. and by the NSFC (No.40739905) to Y. L.

\section{DEPOSITORY MATERIAL}

Table 1 is available online from http://www.jstage.jst. go.jp/browse/jmps.

\section{REFERENCES}

Bai, J.W., Wang, W.X. and Zhang, H.R. (1988) Character of glaucophane schists in metamorphic zone in Yilan, Mudanjiang, Heilongjiang. Acta Petrologica et Mineralogica, 7, 298-308 (in Chinese with English abstract).

Cao, X., Dang, Z.X. and Zhang, X.Z. (1992) Jiamusi complex terrain. pp. 224, Jilin Science and Technology, Changchun, 45-126 (in Chinese with English abstract).

Evans, B.W. (1990) Phase relations of epidote-blueschists. Lithos, $25,3-23$.

Holland, T.J.B. (1983) Experimental determination of the activities in disordered and short-range ordered jadeitic pyroxenes. Contributions to Mineralogy and Petrology, 116, 433-447.

Holland, T.J.B. and Powell, R. (1998) An internally consistent thermodynamic data set for phases of petrological interest. Journal of Metamorphic Geology, 16, 309-343.

Huang, Y.C., Zhang, X.Z., Xiong, X.S., Wang, Y. and Zhao, L.L. (2008) Geochemical characteristics of massive blueschist in Yilan area, Northeast China. Acta Petrologica Et Mineralogica, 27, 422-428 (in Chinese with English abstract).

Kretz, R. (1983) Symbols for rock-forming minerals. American Mineralogist, 68, 277-279.

Leake, B.E., Woolley, A.R., Arps, C.E.S., Birch, W.D., Gilbert, M.C., Grice, J.D., Hawthorne, F.C., Kato, A., Kisch, H.J., Krivovichev, V.G., Linthout, K., Laird, J. and Mandarino, J. (1997) Nomenclature of amphiboles: Report of the subcommittee on amphiboles of the international mineralogical association, commission on new minerals and mineral names.
Mineralogical Magazine, 61, 295-321.

Li, W., Takasu, A., Liu, Y., Genser, J., Neubauer, F. and Guo, X. (2009) ${ }^{40} \mathrm{Ar} /{ }^{39} \mathrm{Ar}$ ages of the high- $P / T$ metamorphic rocks of the Heilongjiang Complex in the Jiamusi Massif, northeastern China. Journal of Mineralogical and Petrological Sciences, 104, 110-116.

Massonne, H.J. and Schreyer, W. (1987) Phengite geobarometry based on the limiting assemblage with $\mathrm{K}$-feldspar, phlogopite, and quartz. Contributions to Mineralogy and Petrology, 96, 212-224.

Nishimura, Y. (1998) Geotectinic subdivision and areal extent of the Sangun belt, Inner Zone of Southwest Japan. Journal of Metamorphic Geology, 16, 129-140.

Otofuji, Y. and Matsuda, T. (1983) Paleomagnetic evidence for the clockwise rotation of Southwest Japan. Earth and Planetary Science Letters, 62, 349-359.

Otsuki, M. and Banno, S. (1990) Prograde and retrograde metamorphism of hematite-bearing basic schists in the Sanbagawa belt in central Shikoku. Journal of Metamorphic Geology, $8,425-439$.

Sengan, H. (1985) Petrography of the Sangun metamorphic rocks in the Hazumi area, Gotsu city, Shimane prefecture. Geological Report of Shimane University, 4, 41-59 (in Japanese).

Sengör, A.M.C., Natal'in, B.A. and Burtman, V.S. (1993) Evolution of the Altaid tectonic collage and Palaeozoic crustal growth in Eurasia. Nature, 364, 299-307.

Takasu, A. (1989) $P-T$ histories of peridotite and amphibolite tectonic blocks in the Sanbagawa metamorphic belt, Japan. In Evolution of metamorphic belts (Daly, J.S., Cliff, R.A. Yardley, B.W.D. Eds.). Geological Society Special Publication, 43, 533-538.

Wilde, S.A., Wu, F.Y. and Zhang, X.Z. (2003) Late Pan-African magmatism in Northeastern China: SHRIMP U-Pb zircon evidence for igneous ages from the Mashan Complex. Precambrian Research, 122, 311-327.

Wu, F.Y., Yang, J.H., Lo, C.H., Wilde, S.A., San, D.Y. and Jahn, B.M. (2007) The Heilongjiang Group: A Jurassic accretionary complex in the Jiamusi Massif at the western Pacific margin of northeastern China. The Island Arc, 16, 156-172.

Ye, H.W., Zhang, X.Z. and Zhou, Y.W. (1994) The texture and evolution of Manzhouli-Suifenhe lithosphere-Study based on features of blueschist and ophiolites. In Geological Studies of Lithospheric Structure and Evolution of Manzhouli-Suifenhe Geotransect, China (M-SGT Geology Group Eds.). Seismic Press, Beijing, 73-83 (in Chinese with English abstract).

\author{
Manuscript received October 15, 2009 \\ Manuscript accepted January 20, 2010 \\ Published online March 15, 2010 \\ Manuscript handled by Masaki Enami
}

